12th LUMEN International Scientific Conference Rethinking Social Action. Core Values in Practice | RSACVP 2019 | 15-17 May 2019 | lasi - Romania

\title{
The Memory Remains: Radu the Great and the Charters of Govora Monastery
}

\author{
Ramona NEACŞA
}

https://doi.org/10.18662/lumproc. 167

How to cite: Neacşa, R. (2019). The Memory Remains: Radu the Great and the Charters of Govora Monastery. In C. Ignatescu (ed.), 12th LUMEN International Scientific Conference Rethinking Social Action. Core Values in Practice, 15-17 May 2019, Iasi - Romania (pp. 217-224). Iasi, Romania: LUMEN Proceedings. https://doi.org/10.18662/lumproc.167 



\title{
The Memory Remains: Radu the Great and the Charters of Govora Monastery
}

\author{
Ramona NEACŞA ${ }^{1 *}$
}

Abstract

In this paper we analyse the charters of Govora Monastery, not only from the perspective of their contents, but also with an accent on the chancellery form of the documents. At the end of the 15th and during the 16th centuries the monasteries were not only a network of religious and economic centres, but also bubs of political power. Govora Monastery makes no exception and, after a flourishing period during the reins of Vlad the Monk and especially Radu the Great, it remained emblematic, for their descendants, as a foundation of the Drăculesti dynasty. These charters demonstrate that Govora's prestige of princely foundation is used as a field of legitimacy discourse by the princes who ruled Wallachia in the 16th century (Neagoe Basarab, Radu from Afumati, Mircea the Shepherd, to mention just a few of them), keeping alive the memory of Radu the Great, and are also interesting because they preserve, like in a time capsule, fragments of the political struggles from the beginning of the 16th century, thus becoming true treasures of the social memory. The novelty of this type of research, even if it takes a lot of patience to do and is often challenging, is that the information discovered or infered from charters confirm, invalidate or explain historical events about which we have scarce knowledge from other sources. We are sure that the future studying of the chancellary documents will continue to unveil fscinating historical facts.

Keywords: Radu the Great; Govora Monastery; charters; princely legitimacy; discourse of power.

\section{Introduction}

The ideology of power of the Wallachian princes, at the end 15 and early $16^{\text {th }}$ century, is an interesting theme which never stops fascinating us. We can analyze their discourse in different and yet complementary sources, be they the first chronicles, hagiographic texts, the iconography of churches,

\footnotetext{
${ }^{1}$ Lect. PhD, "Valahia" University of Târgoviște; ramonaneacsa@gmail.com This study was made during the research project The Circle of Power: Wallachia's Council during the reign of Radu the Great" financed by UEFISCDI, PN-III-P1-1.1-PD-2016-0626, PD158 from $10 / 10 / 2018$.
} 
the letters that endured the passing of time or the princely charters. In the present paper we chose to analyze the charters of Govora monastery. The novelty of this type of research, even if it takes a lot of patience to do and is often challenging, is that the information discovered or infered from charters confirm, invalidate or explain historical events about which we have scarce knowledge from other sources. Compared to the aforementioned sources, the charters have a specific advantage: the discourse of the prince can be more easily identified because of the deviations from the chancellery form which at the beginning of the 16 century was quite standardized. Thus, any deviation from this form, either at the intitulatio, the content of the charter, the curse part or the princely council, suggests the lord's intention to transmit a certain message, to a certain audience [3]. On the other hand, the charters are interesting because they preserve, like in a time capsule, fragments of the political struggles from the past, thus becoming true treasures of the social memory. The challenge is to reconstruct the historical context which to allow us to frame the pieces of information we discovered and to decipher the signification of the elements of discourse of power.

\section{Theoretical Background}

A standard complete charter includes the arenga, the content of the document, the princely curse and the princely council. The study of the medieval Wallachian charters was a priority for many historians, like Damian P. Bogdan, George D. Florescu, Nicolae Stoicescu, Aurelian Sacerdoțeanu, but also some modern historians like Ștefan Andreescu and Marian Coman. It is true that the content of the charters is very important and most of the historians prefered, until recent times, to skip the intitulatio directly to the content. Of all the diplomatic formulas of a standard charter, the arenga was the most despised by the Romanian mediaevalists. According to Damian P. Bogdan, the arenga is a mere enounciation of the reason why the document was issued, „often insipid and with no direct connection with the object of the document.... much like a literary adornment, unessential for the text" [1]. Only in the last couple of years, historians like Marian Coman begun to make justice to this part of the chancelary documents, by analyzing them and and underlining their importance. As for the last parts of the charters, if the curse enjoyed an increased attention, maybe because of its spectacular aspect, the part of the witnesses, of the princely council, was almost completely ignored. Our purpose is to take into account all the component parts of the documents concerning Govora Monastery and search, within them, the voice of the prince. 


\section{In search of the holy Monastery's beginnings}

As I already explained in a previous study [10] the known documents don't indicate a date for the foundation of the monastery. In the donation acts with which the lords were confirming the possessions of the monasteries or in which they made new ones, were often mentioned the first founders, in order to be mentioned in the diptych, according to their quality of founders. With this occasion we find out who was the first founder of that specific monastery. From a charter issued by Vlad the Monk, at 4 February 1488, in which he endowed Govora monastery with the village of Hința, we find out that his donation was made "for the memorial service of my late forefathers." [4] From here we conclude that Vlad the Devil must have been the first founder, otherwise the mentioning of his name in the diptych would not be justified, and he might have been the first, because no other forefather is mentioned. It would be hard to belive that Vlad the Monk would have deliberately missed the mentioning of a predecessor like, say, Mircea the Ancient. Nevertheless, we have to mention that in another charter Radu the Great says that the found the church "abandoned by the righteous and blessed founders, our grandfathers and great-grandfathers ... which is why we desired towards the holy monastery, after the happy passing of the ... aforementioned grandfathers and great-grandfathers" [4]. This mentioning of the great-grandfathers might indicate a more ancient existence of the church, Radu the Great's grandfather being Mircea the Ancient. It might be possible that at its beginnings the foundation was not a monastery and was actually build on an older ecclesial foundation.

In several subsequent charters we discover Vlad the Devil taking care of the monastery's wellbeing. In a charter given to Govora in 1496, we find out that he bought at Copăcel, near Ocnele Mari, a vineyard, which he afterwards donated to the monastery [4], along with a mill at Râmnic. We find again these two possessions in charters from 1502, "and again we give the mill from my princely town Râmnic and ... the vineyard from Copăcel, for it was given by my grandfather, the great Vlad the Devil" [5]. We can therefore say that Vlad the Devil was likely the founder of the monastery.

In 1457 it already existed, for in this year Vlad the Impaler gave it a bell, on which his patron, Saint Nicholas, was invoked. [2]. Later on Albul the Great distroyed Govora, named himself prince of Wallachia over Vlad the Impaler's head, then, in 1459, the year in which Vlad the Impaler slaughtered many boyars, he also killed him and all his kin and the holy monastery, being abandoned, gave its possessions to some faithful servants. After his ascension to the throne, Vlad the Monk begun the restauration of the monastery. At 4 February 1488 he repurchased Hinţa and donated it to 
the holy foundation "and to all the brothers into Christ from that holy monastery" [4], and from this we understand that it still functioned, thou in very poor conditions. Radu the Great, his son, increased the restauration activity - he build from foundation a whole new monastery and endowed it with many lands, either confirming old ones, or buying all new ones. Thus entered in Govora monastery's possession Hința, Glod, Nănişeşti, Nănăşeşti, Mirileşti, Arghiş, Pirot, Ioneşti, the vineyard from Ocne, Stoiceani and many others [4]. Soon enough the lawsuit for the possession over these lands have begun and, although long debated and controversed, Vlad the Monk and Radu the Great insist in appearing the purchasers of these aforementioned villages, all of them in the Argeş area.

In contrast with the concern shown by the Drăculeşti descendants to Govora, the members of the Dăneştii dynasty who occupied the throne of Wallachia up until Clad the Monk and after Radu the Great's death are not evoked in the charters of the monastery.

\section{Some charters given by Neagoe Basarab}

Up until Neagoe Basarab, Mihnea the Evil and Vlad the Young do nothing more than to confirm Govora's possessions, in two simple charters [5]. Things change during the reign of Neagoe Basarab. In 1517 the monastery received a charter in which all its previous possessions were confirmed. As Marian Coman observed, at first sight the document, the most extensive charter of Govora preserved from the $15^{\text {th }}-16^{\text {th }}$ centuries, seemed ordinary, but at a closer look some particularities emerged. One of them is the unusual place in which the document was issued: ,in the throne of the old lords, in the princely court of Arges.." This formula suggests a certain type of historical legitimacy - for 70 years the issue of a charter from the princely court of Argeş was no longer an usual thing [3] [5]. Another particularity is the mentioning in the arenga of Neagoe's son, Teodosie: „Io Basarab Voivod ... lord of the entire Ungrovlahia and with the God given son of mine, Io Teodosie Voivod", this being the only charter in which this name appears. It is worth mentioning that 1517 is the year when Teodosie, at age 12, was associated by his father at the throne of Wallachia. In this context, the issuing of the document from 30 October 1517 may explain the changing of the usual chancellery form by integrating within its lines a dynastic discourse [3].

The most interesting particularity of the charter of Govora is the precise mentioning of the Wallachian rulers: „the ancient Vlad Voivod Drăculea“, „Basarab Voivod the Young the Impaler“, „Vlad Voivod the Monk“ „Radul Voivod, son of Vlad Voivod“ and „Samonida, mother of 
Radu Voivod." The charter has the aspect of a dynastic history in which Neagoe Basarab himself, his father, Basarab the Impaler and his son, Teodosie, are carefully inserted in the line of the Wallachian rulers. All these special features demonstrate that the charter of Govora was not a simple document which confirmed previous possessions, but an opportunity to present a legitimacy discourse of the princely power [3]. In our opinion this discourse was destined to a special audience, namely the monks from the monastery and it might be useful to remember that during the medieval centuries the holy foundations have played an important part in the legitimation of the princely power. Why Govora and not any other? Maybe because this monastery was emblematic for the foundational activity of Radu the Great and, by joining the gallery of churchwardens, Neagoe Basarab was borrowing some of his great predecessor's prestige, consolidating his legitimacy even more.

Most of Radu the Great's successors - and he had no less than 11 descendants to the throne - have built their public image as his sons or direct heirs - for instance Radu from Afumați, Radu Bădica, Vlad Vintilă, Radu Paisie or Mircea the Shepherd. Except for Vladislav the III ${ }^{\text {rd }}$, one of the last heirs of Dăneşti dynasty, all the rulers of Wallachia paid a special attention to Govora Monastery which, up until Alexandru II Mircea, has received over 50 charters.

\section{From Radu from Afumati to Alexandru II Mircea}

Radu the Great and Neagoe Bsarab were two lords who knew how to keep the boyar families at bay, families which were getting stronger from the second half of the $15^{\text {th }}$ century, the first one using a keen politics, the second by making a huge effort and a skillfully constructed strategy. If during their lifetime these forces were maintained in a latent state, after their death they crashed in violent confrontations.

The internal chronicles mention, after Radu the Great's death, the conflictual situation which existed within the political class and the Ottoman Porte's meddling in the succession to the Walachia's throne was one of the factors which increased the divergences between the boyar families. The short but violent rule of Mihnea the Evil, the fierceness with which he punished the boyars, his predecessor's relatives and the counselors and his attitude towards the members of the Craiovesti family did nothing more than to deepen the conflict. Neagoe Basarab has managed to gather around him a group of faithful boyars, from the most important families in the country, his rule being not a very quiet one, as the internal chronicles show, 
not troubled by major unfavorable events. Despite the disputes which appeared between the boyars after his death, when no less than 6 pretenders endangered Teodosie's rule, when Mehmed bey seemed that he will obtain the investiture from the sultan, they accepted, as solution, to choose Radu from Afumați. The fights against the Turks from 1522-1524 bring to the battlefield most of the boyars.

The charters of Govora capture a fragment of this reality. Generally, when a monastery receives an estate, its recovery by the former owners becomes practically impossible, even thou, theoretically, the princely judgements were possible.

A special situation is encountered in the charters about Stoiceani, which was bought by Radu the Great with 6000 aspri, because it had been received as dowry by his mother, Lady Samonida [4] ("and all the Stoicianii, for they were given as dowry to our mother by her parents") who, at her turn, after becoming a nun, gave it to the monastery.

We assume that it was a quite large estate because, later on, several appellants request judgement for different parts of it. The sons and grandsons of Vlaicu, the one who sold the village to Radu the Great, reclaim the lost village: "And the Father Superior and the other monks were respondent before us, with Vlaicu's sons ... and grandsons... for that village, Stoicianii. ... and we read the charters of the late Radu Voivod... . But Vlaicul sold Stoicianii by his own will" [6]. It is a judgement made by Radu Paisie and, in june 1547, Mircea the Shepherd judges a similar case. Again the monastery wins the trial.

A special situation is encountered in one of the charters issued by Radu from Afumaţi, at 30 May 1526, for faithfull service, to Manea vornic, Tudor clancellor and to their wives, Dumitra and Vlădae. About the beneficiaries of the donation it is said that "they served for a long time and never have they shown unfaithfulness, not did they turn their backs to the enemy, but they spilled their blood for our lordship..." [7]. The donation is given on a part of the estate "Stoicenilor, which was taken over by the Drăculești boyars...”

The first unusual thing which strikes us is the use of the term "Drăculești", for Radu from Afumați, as Radu the Great's son, was also a member of the Drăculeşti dynasty. Second, we have to specify that at this date it is the only part of the Stoiceani estate about which we know that is no longer part of the Govora Monastery's possessions, as decided by Radu the Great. Last, but not least, the document seems to be an echo of a conflict between two boyar sides, a conflict that doesn't end too soon. At 5 October 1568-1573, Alexandru II Mircea judges in favor of the monastery, 
to keep the estate for which it came to judgement against the Drăculești, "for it belongs to the holy monastery. And you, when you will see this charter of my judgement, stay away from the estate of the holy monastery..." [8]

Who are the two officials for whome Radu from Afumați decided in their favor in the case against the Drăculești? The chancellor Tudor from Drăgoești and the vornic Manea Perșanu were brothers in law. The first, who was married with Dumitra, was a close boyar of the lord, most likely being the one who wrote, in 1525, at Radu from Afumați's request, the first slavic chronicle. He had fought alongside Radu from Afumați against the Turks, being one of the few boyars left alive after the fights against Mehmed, a fact which also explains the donation for faithful service. The second, the vornic Manea Perșanu, was married with Vlădae, who had possessions in Stoiceani, was a brother in law of Tudor chancellor and a close counselor to the prince. Even if we do not know his kin, we know that he was rich enough to build the Church Sfânta Vineri from the Princely Court of Târgovişte (1517), a town in which he build another church and where he had couses. He, too, had fought alongside Radu from Afumati and his brother in law against the Turks. We are therefore dealing with two powerful officials who were close to the prince, and the fact that they were rewarded for their acts of bravery in an act involving Govora Monastery is not random. It is not the first time that donations were made for acts of bravery and the document does not mention the reasons for the donation, but it is nontheless an act of great honor for the two beneficiaries. Of course, we cannot unravel the entire historical picture using only the charters of Govora.

\section{Conclusions}

Apart from the fact that they preserve the memory of some internal political struggles from the beginning of the $16^{\text {th }}$ century, these charters demonstrate that Govora's prestige of princely foundation is used, just like in many other situations, as a field of legitimacy discourse. For Mircea Ciobanul, who demonstratively narrates suggestive episodes from the history of the holy foundation, the regulation of the disputes concerning Govora becomes a good oportunity to relate himself to his famous father's deeds, thus ensuring the continuity with "the lords and emperors ... whose souls pleased the Lord" [9]. For his and for the other descendants of Radu the Great Govora was a place with a tradition of power, a symbol of the connection with the predecessors and of asserting the princely durability and legitimacy. 


\section{References}

[1] Bogdan D.P. Diplomatica slavo-română din secolele XIV şi XV“. Revista istorică română. 1937. vol. 7. p. 74-121.

[2] Chihaia P. Ctitorii ale voievozilor Drăculeşti. In Artă medievală. III. Țara Românească între Bizanț şi Occident. Bucharest: Editura Albatros

[3] Coman M. În scaunul vechilor domni. In: Mărturii. Frescele Mănăstirii Argeşului. Bucharest: Muzeul Național de Artă al României. 2012-2013. p. 4449.

[4] Documenta Romaniae Historica. B. Țara Românească. Vol. I (1247-1500). Petre P. Panaitescu, Damaschin Mioc, editors. Bucharest: Editura Academiei. 1966.

[5] Documenta Romaniae Historica. B. Ţara Românească. Vol. II (1501--1525). Ştefan Ştefănescu, Olimpia Diaconescu, editors. Bucharest: Editura Academiei. 1972.

[6] Documenta Romaniae Historica. B. Țara Românească. Vol. IV (1536-1550). Damaschin Mioc editor. Bucharest: Editura Academiei. 1981.

[7] Documenta Romaniae Historica. B. Țara Românească. Vol. III (1526-1535). Damaschin Mioc editor. Bucharest: Editura Academiei. 1975.

[8] Documenta Romaniae Historica. B. Țara Românească. Vol. VI (1566-1570). Stefan Stefanescu, Olimpia Diaconescu editors. Bucharest: Editura Academiei. 1985.

[9] Documenta Romaniae Historica. B. Țara Românească. Vol. V (1551-1565). Damaschin Mioc, Marieta Adam Chiper editors. Bucharest: Editura Academiei. 1983.

[10] Neacşa R. "Şi încă a pustiit şi sfânta mănăstire”. Mănăstirea Govora şi un gest de putere de la mijlocul secolului al XV-lea. SMIMM. 2015. Vol. XXXIII. p. 267-286. 